\section{Pacific Northwest}

National Laboratory

Operated by Battelle for the

U.S. Department of Energy

\title{
Mechanical Properties of K Basin Sludge Constituents and Their Surrogates
}

\author{
C. H. Delegard \\ A. J. Schmidt \\ J. W. Chenault
}

November 2004

Prepared for the U.S. Department of Energy under Contract DE-AC05-76RL01830 


\title{
DISCLAIMER
}

This report was prepared as an account of work sponsored by an agency of the United States Government. Neither the United States Government nor any agency thereof, nor Battelle Memorial Institute, nor any of their employees, makes any warranty, express or implied, or assumes any legal liability or responsibility for the accuracy, completeness, or usefulness of any information, apparatus, product, or process disclosed, or represents that its use would not infringe privately owned rights. Reference herein to any specific commercial product, process, or service by trade name, trademark, manufacturer, or otherwise does not necessarily constitute or imply its endorsement, recommendation, or favoring by the United States Government or any agency thereof, or Battelle Memorial Institute. The views and opinions of authors expressed herein do not necessarily state or reflect those of the United States Government or any agency thereof.

\author{
PACIFIC NORTHWEST NATIONAL LABORATORY \\ operated by \\ BATTELLE \\ for the \\ UNITED STATES DEPARTMENT OF ENERGY \\ under Contract DE-AC05-76RL01830
}

This document was printed on recycled paper. 


\title{
Mechanical Properties of K Basin Sludge Constituents and Their Surrogates
}

\author{
C. H. Delegard \\ A. J. Schmidt \\ J. W. Chenault
}

November 2004

Prepared for

the U.S. Department of Energy under Contract DE-AC06-76RL01830

Pacific Northwest National Laboratory

Richland, Washington 99352 


\section{Summary and Conclusions}

This report summarizes the mechanical and physical properties of Hanford K Basin sludge constituents and includes the results of hardness measurements performed on irradiated uranium metal fuel. Understanding the characteristics and behavior of the sludge constituents is important for selecting appropriate surrogate materials for use in testing pumps and associated equipment that will be used for transferring and handling the sludge as a slurry for treatment and disposal. The inorganic components of the sludge include irradiated uranium metal and its radioactive corrosion products, such as uranium dioxide $\left(\mathrm{UO}_{2}\right)$, as well as non-radioactive materials. The mechanical properties of the irradiated uranium and its oxides are especially important, because they are very high density, hard materials with potentially jagged, sharp particle geometry that could be a challenge to slurry handling equipment.

In slurry pumping, the solid sludge particles will be lifted and transported by high-velocity water. The high velocities, which are required to keep the dense uranium particles suspended, can cause significant wear on the slurry transfer equipment. Consequently, testing is being conducted to characterize and evaluate the performance of candidate pump and handling equipment. These tests require the identification/specification of non-radioactive surrogates for the radioactive components of the sludge. The surrogates must have mechanical properties (principally particle size distribution, shape, density, and mechanical hardness) similar to the irradiated uranium metal and uranium dioxide (and other sludge components). The impact strength of the simulant ("toughness to impact fracturing") also is important with respect to its impingement on the pump's internal parts. This is particularly true in some engineering tests when a small quantity of simulant is recycled hundreds of times in a closed loop to represent the transfer of a large volume of sludge.

The literature review showed that uranium metal hardness increased steeply with radiation exposure to $1260 \mathrm{MWd} / \mathrm{t}$, but information was lacking on the hardness of uranium metal at the exposures received by the N Reactor fuel stored in the K Basins (typically up to $3000 \mathrm{MWd} / \mathrm{t}$ ). As a result, this study included hardness measurements of irradiated uranium metal, using $\mathrm{N}$ Reactor fuel sample coupons from three different fuel elements. Samples were taken from the broadest available range of locations within the fuel elements - along the axial length of the elements near the end and the middle, and from faces directly under cladding and within the "meat" of the fuel on cut faces.

The hardness of the fuel coupons was measured with a commercial penetrometer device (Ames Model 1 Portable Hardness Tester) modified for hot cell application. The coupon hardness values, measured in Rockwell $\mathrm{C}$ units, averaged $30 \pm 8$ and were not appreciably different from the values reported in the technical literature for the lower-exposure uranium irradiated to $1260 \mathrm{MWd} / \mathrm{t}$. Hardness values were greater underneath the cladding, but were not measurably different when obtained over the fuel length. The hardness values were significantly lower than that of the tungsten carbide (i.e., Rockwell C of 69 to 74) used to represent irradiated uranium metal in previous K Basin sludge simulants.

The density and hardness of the two primary uranium corrosion products, uranium dioxide and schoepite, also were reported in the technical literature. The hardness of $\mathrm{UO}_{2}$ is equal to, or greater than, that of any non-uranium phase, and its density is higher. While $\mathrm{UO}_{2}$ particles are expected to be micron-scale, some accreted uranium-rich particles have been observed in sludge. Therefore, the mechanical aggressiveness of $\mathrm{UO}_{2}$ is also likely to be greater than that of any non-uranium sludge phase. The density and hardness values show that the mechanical aggressiveness of the non-uranium sludge components is bounded by 
quartz and basalt. Schoepite hardness and density are matched well by non-uranium sludge phases and contribute no added mechanical aggressiveness to the sludge.

The mechanical/physical properties of uranium metal and uranium dioxide were compared with their candidate surrogates. Surrogates having properties closest to those of irradiated uranium metal from $\mathrm{N}$ Reactor fuel appear to be alloys of tungsten. Based on hardness and impact strength and a review of the materials available, the tungsten material recommended for use as irradiated uranium metal surrogate is Densalloy SD170 or equivalent. The surrogate for uranium dioxide, present both as particles and agglomerates in actual $\mathrm{K}$ Basin sludge, likely requires two materials in order to cover the range of particle sizes. Commercially available materials- $\mathrm{CeO}_{2}$, to represent the smaller particles, and steel grit, for the agglomerates-were identified for the $\mathrm{UO}_{2}$ surrogates. 


\section{Contents}

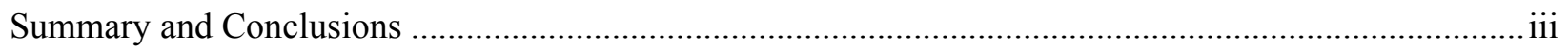

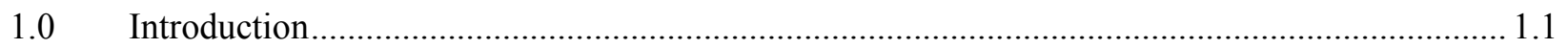

2.0 Technical Literature Review of Sludge Component Properties............................................. 2.1

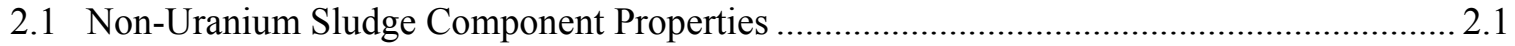

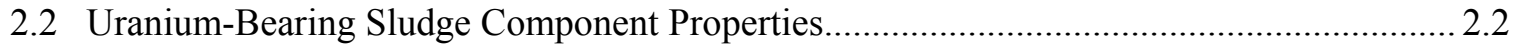

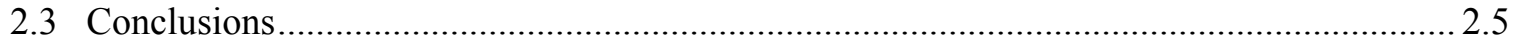

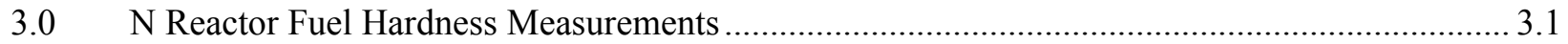

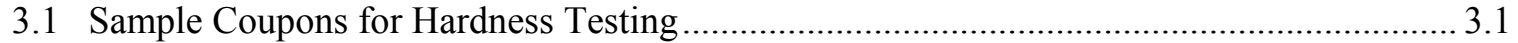

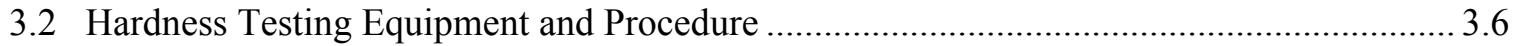

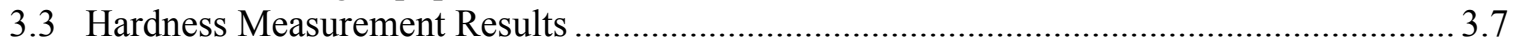

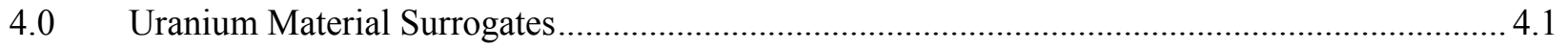

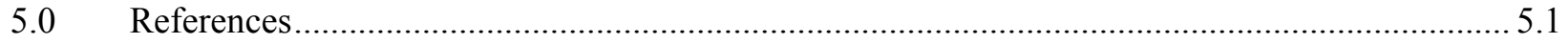





\section{Figures}

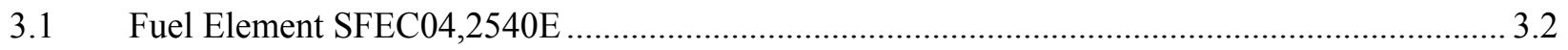

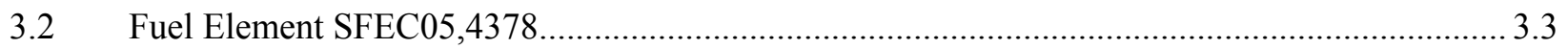

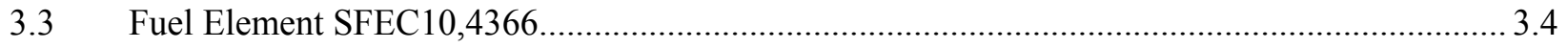

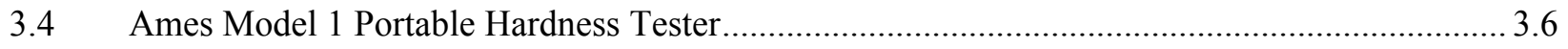

3.5 Coupon 5-S1A-J2B7 Before, During, and After Hardness Measurements ................................ 3.9 


\section{Tables}

2.1 Non-Uranium Sludge Component Material Properties........................................................ 2.2

2.2 Uranium Sludge Component Material Properties.................................................................... 2.3

2.3 Uranium Metal Strength as a Function of Irradiation ...................................................... 2.4

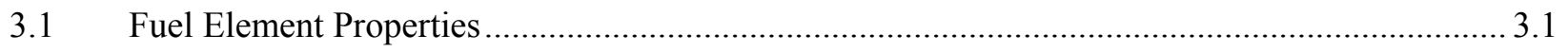

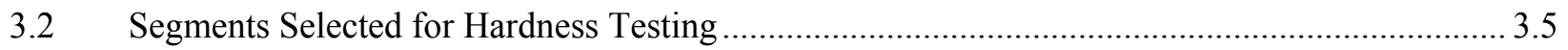

3.3 Hardness Measurement Results for N Reactor Fuel Coupons ............................................... 3.8

4.1 Uranium Sludge Component and Surrogate Material Properties ................................................ 4.2 


\subsection{Introduction}

The sludge contained in the Hanford K East (KE) and K West (KW) Basins is being removed and disposed of as part of the overall $\mathrm{K}$ Basin decontamination and decommissioning efforts. This sludge, which accumulated during the time that $\mathrm{N}$ Reactor fuel was stored in the basins (and, in the case of KE Basin, from operations in the 1950s) is composed of products of the fracture and subsequent corrosion of irradiated uranium metal fuel, along with sand (from sand filters), infiltrated soils, steel, aluminum, and concrete structural component corrosion products, organic and inorganic ion exchange materials, and miscellaneous debris. In the $\mathrm{K}$ Basin Closure Project, sludge is defined as any particulate material that can pass through a screen with $1 / 4$-in. $(\sim 6350 \mu \mathrm{m})$ openings (Schmidt 2004$)$.

A system is being design to transfer KE canister and floor sludge to containers in the KW Basin. The sludge transfer system, referred to as the hose-in-hose system (HIHS), is expected to include approximately $2500 \mathrm{ft}$ of 1.25 -in. hose with four booster pump stations located approximately every $500 \mathrm{ft}$. Because $\mathrm{K}$ Basin sludge contains large particles (up to $1 / 4 \mathrm{in}$.) with specific gravities up to $19 \mathrm{~g} / \mathrm{cm}^{3}$ (uranium metal), high line velocities are needed to transport it without settling in the transfer line. However, the high velocities and impingement of the sludge solids can cause wear on the slurry pumping hardware, as observed in engineering tests conducted by Washington State University (WSU), under the direction of BNFL, Inc. These tests, which were conducted to evaluate slurry flow characteristics and the effects of transporting a KE canister sludge simulant on candidate hose material and fittings, used tungsten carbide fragments and sintered tungsten metal granules for the uranium metal surrogate. While the abrasive slurry had little impact on the hose material and fittings, the pump used in the testing suffered seal failures and severe erosion to the impeller and housing.

The simulant used in the WSU testing was very conservative relative to nominal KE Basin sludge, particularly with respect to the tungsten carbide used to represent actual irradiated uranium metal. Therefore, a more realistic surrogate for uranium metal in follow-on pump erosion testing is needed to validate the selection of materials of construction and designs of pumps in the HIHS. In developing surrogates, the foremost mechanical and physical properties of the sludge components are density, hardness, and particle size and shape. Also of importance is the physical toughness of the irradiated uranium metal to withstand impact (i.e., ductility versus brittleness). This latter characteristic is particularly important in the surrogate if engineering tests use only a small quantity of sludge simulant recycled repeatedly, in a closed loop, to represent the transfer of a large quantity of actual sludge at the basins.

The study discussed in this report was conducted to survey the technical literature to identify the most representative mechanical and physical properties of sludge components, in particular, the irradiated uranium metal and uranium dioxide (represented in actual sludge by compounds ranging from $\mathrm{UO}_{2}$ to $\mathrm{U}_{3} \mathrm{O}_{7}$ ). Particle size distribution has been described elsewhere (Schmidt 2004) and is not further examined here. The literature review showed that uranium metal hardness increased steeply with radiation exposure to $1260 \mathrm{MWd} / \mathrm{t}$, but information was lacking on the hardness of uranium metal at the exposures received by the $\mathrm{N}$ Reactor fuel stored in the K Basins (typically up to $3000 \mathrm{MWd} / \mathrm{t}$ ). As a result, this study also included hardness measurements of typical irradiated uranium metal fuel coupons taken from the K Basins. From the literature review and hardness measurements, candidate surrogate materials for the sludge simulants were identified. 
The following materials were considered in this study:

\section{Uranium Metal and Candidate Uranium Metal Surrogates}

- Tool steel

- W/Co (cobalt-cemented tungsten carbide)

- Tungsten

- Tungsten wire

- Densalloy SD185; 97 wt\% W

- Densalloy SD170; $90 \mathrm{wt} \% \mathrm{~W}$

- 304 stainless steel

- Monel 400

- Garnet

\section{Uranium Dioxide and Candidate $\mathrm{UO}_{2+\mathrm{x}}$ Surrogates}

- A434L stainless steel

- $\mathrm{CeO}_{2}$ (product $5310,50 \%<15.1 \mu \mathrm{m}$ )

- Steel grit (HG hardness; G40 - 100\% $<1000 \mu \mathrm{m}, 30 \%<425 \mu \mathrm{m}, 20 \%<300 \mu \mathrm{m}$ )

The data collected from the literature review of the non-uranium and uranium-bearing sludge are presented in Section 2.0. The hardness measurement results are given in Section 3.0, and proposed candidate materials are discussed in Section 4.0. 


\subsection{Technical Literature Review of Sludge Component Properties}

This study was conducted to gather data on the pertinent mechanical and physical properties, including hardness, of solids in K Basin sludge. No data were found in the technical literature for the hardness of irradiated uranium metal at the maximum exposures received by the $\mathrm{N}$ Reactor fuel stored in the K Basins (typically up to $3000 \mathrm{MWd} / \mathrm{t}$ ). However, the trend of the data available indicated that hardness increases as uranium is irradiated to higher burnups. Consequently, this study also included hardness measurements of irradiated N Reactor fuel coupons (results are presented in Section 3.0).

Hardness is measured in a number of ways, and the data are reported in various measurement scales. For example, the hardness of minerals often is measured using the Moh scale, in which the relative abilities of minerals to scratch each other are ranked. A similar approach involves scratching metals with files of known hardness. Most often, however, hardness is measured using penetrometer methods. The depth of penetration of a probe (of fixed geometry and construction material) after reaching, and sometimes relaxing, a set load is measured and related to a scale. Alternatively, the size of the indentation made by the penetrometer may be measured. Another type of hardness test (sclerometer) measures the rebound height of a hammer dropped onto the material to be tested. The rebound height is compared to that of pure hardened high-carbon steel.

The Vickers, Knoop, Brinell, and Rockwell hardness tests use penetrometers. The Rockwell tests have a number of hardness scales varied by the applied load and the penetrometer shape and material of construction. Correlation within the Rockwell and other penetrometer scales is made by using an American Society for Testing and Materials comparison (ASTM 2002a).

In this study, the hardness of irradiated uranium metal was measured with a Rockwell penetrometer calibrated in the "C" scale (often designated as HRC in the technical literature). Therefore, hardness values reported in other scales were correlated with the Rockwell $\mathrm{C}$ hardness scale, where possible, using the ASTM basis noted. The correlation of Moh hardness to other hardness scales is approximate.

\subsection{Non-Uranium Sludge Component Properties}

The non-uranium sludge components primarily consist of silica sand, aluminum hydroxide, hydrous ferric oxides/hydroxides, and soil minerals (Makenas et al. 1996-1999; Pearce 2001). The sludge also contains irregular shards of the Zircaloy cladding that encased the N Reactor fuel. Present in much smaller quantities are organic materials (paint chips, plastic, biological debris, polychlorinated biphenyls), Grafoil (a graphite-based gasketing material), and other inorganic materials.

Many of the KE Basin fuel canisters were constructed with aluminum metal. Corrosion of the aluminum has produced all three $\mathrm{Al}(\mathrm{OH})_{3}$ isomorphs (gibbsite, bayerite, and nordstrandite) as found by X-ray diffractometry (XRD), with gibbsite the most prevalent. Structural mild steel used to construct fuel storage racks in the KE Basin resulted in iron corrosion products observed by XRD in the KE sludges. Two FeOOH phases have been seen, lepidocrocite and goethite. These phases dehydrate to hematite, $\mathrm{Fe}_{2} \mathrm{O}_{3}$, also observed in the sludge. Less crystalline hydrous iron oxides, including ferrihydrite, $\mathrm{Fe}_{5} \mathrm{O}_{7} \mathrm{OH} \cdot 4 \mathrm{H}_{2} \mathrm{O}$ (Majzlan et al. 2004), though not confirmed by XRD, are also likely. The most conspicuous mineral phase identified by XRD in the sludge is quartz, $\mathrm{SiO}_{2}$. The quartz originates from sand filters, from concrete degradation, and from in-blown native soils. Calcite $\left(\mathrm{CaCO}_{3}\right)$ is present from in-blown soil and concrete degradation. Smaller quantities of anorthite $\left(\mathrm{CaAl}_{2} \mathrm{Si}_{2} \mathrm{O}_{8}\right)$ and mica also are 
found from native soils. Basalt, largely X-ray indifferent in its glassy phase but also containing anorthite, is present from in-blown soils and as aggregate in concrete. Note that while crystalline phases can be identified by XRD analyses, amorphous material phases in the sludge (e.g., glass, plastic, biological matter, very fine inorganic particulates) would not be detected. Except for the glass present in basalt, the $\mathrm{X}$-ray indifferent phases would pose no unique hazard to the pump apparatus.

The physical properties of the non-uranium sludge components are summarized in Table 2.1. It is seen that the upper limit in material hardness for the non-uranium components is defined by quartz and basalt. These two materials also are among the non-uranium sludge phases with the largest particles. Although some of the $\mathrm{Al}(\mathrm{OH})_{3}$ is present as nodules with diameters up to $2 \mathrm{~cm}$ (Baker 2001), the $\mathrm{Al}(\mathrm{OH})_{3}$ hardness is low; the nodules, when contacted during sludge sampling, were observed to break easily and thus are expected to be readily pulverized during retrieval and pumping. The iron-bearing phases, $\mathrm{FeOOH}$ and $\mathrm{Fe}_{2} \mathrm{O}_{3}$, have densities higher than quartz, but their particles, which arise from structural steel corrosion, are micron-scale (as evidenced by their ready suspension in agitated $\mathrm{K}$ Basin waters) and their hardnesses lower than found for quartz and basalt. The predecessor phase, ferrihydrite, likely has a smaller particle size than the $\mathrm{FeOOH}$ and $\mathrm{Fe}_{2} \mathrm{O}_{3}$ phases and, being more hydrated, a lower density as well. However, no data were found on its density or hardness. Zircaloy, though having relatively high density, is a very soft material and is present as cladding in bits and shards only $0.33-\mathrm{mm}$ (inner) to $0.61-\mathrm{mm}$ (outer) thick. Similarly, small quantities of aluminum cladding pieces from damaged Single Pass Reactor (SPR) fuel also may be present. Like Zircaloy, the aluminum cladding is very soft. Any residual aluminum cladding may, in fact, already be corroded to $\mathrm{Al}(\mathrm{OH})_{3}$.

Table 2.1. Non-Uranium Sludge Component Material Properties

\begin{tabular}{|c|c|c|c|c|c|c|}
\hline \multirow{3}{*}{$\begin{array}{l}\text { Non-Uranium } \\
\text { Sludge Phase }\end{array}$} & \multirow{3}{*}{$\begin{array}{c}\text { Particle } \\
\text { Density, } \\
\text { g/cm }\end{array}$} & \multicolumn{4}{|c|}{ Hardness } & \multirow{3}{*}{ References } \\
\hline & & \multirow{2}{*}{ Moh } & \multicolumn{3}{|c|}{ Rockwell Scale } & \\
\hline & & & A & B & $\mathrm{C}$ & \\
\hline Gibbsite, $\mathrm{Al}(\mathrm{OH})_{3}$ & 2.40 & $2.5-3.5$ & $\sim 24$ & $\sim 25$ & $<2$ & $\begin{array}{l}\text { Roberts et al. } \\
\text { (1990) }\end{array}$ \\
\hline $\begin{array}{l}\text { Ferrihydrite, } \\
\mathrm{Fe}_{5} \mathrm{O}_{7} \mathrm{OH} \cdot 4 \mathrm{H}_{2} \mathrm{O}\end{array}$ & - & - & - & - & - & - \\
\hline $\begin{array}{l}\text { Lepidocrocite and } \\
\text { Goethite, FeOOH }\end{array}$ & $3.3-4.3$ & $5-5.5$ & $71-74$ & - & $41-48$ & \multirow{5}{*}{$\begin{array}{l}\text { Roberts et al. } \\
\text { (1990) }\end{array}$} \\
\hline Hematite, $\mathrm{Fe}_{2} \mathrm{O}_{3}$ & 5.3 & $5-6$ & $71-78$ & - & $41-54$ & \\
\hline Quartz, $\mathrm{SiO}_{2}$ & 2.65 & 7 & 83 & - & 63 & \\
\hline Anorthite, $\mathrm{CaAl}_{2} \mathrm{Si}_{2} \mathrm{O}_{8}$ & 2.75 & $6-6.5$ & $78-81$ & - & $54-60$ & \\
\hline Calcite, $\mathrm{CaCO}_{3}$ & 2.71 & 3 & 24 & 25 & $<2$ & \\
\hline Basalt & 2.75 & $5.5-7$ & $74-83$ & - & $41-63$ & Ladoo (1960) \\
\hline Zircaloy & 6.56 & - & 49 & - & $<2$ & \multirow{2}{*}{ Ross (1992) } \\
\hline Aluminum & 2.7 & - & - & - & $<2$ & \\
\hline
\end{tabular}

\subsection{Uranium-Bearing Sludge Component Properties}

Uranium materials in the sludge include the uncorroded irradiated (and some non-irradiated) uranium metal and the corrosion products from the interaction of the uranium metal with basin water containing dissolved oxygen and low concentrations of dissolved minerals. The following phases that develop from uranium metal corrosion and oxidative paragenesis have been observed by XRD of sludge samples: uranium hydride $\left(\mathrm{UH}_{3}\right)$; "uranium dioxide" (uraninite, $\mathrm{UO}_{2+x}$ present as $\mathrm{UO}_{2}$ to $\mathrm{UO}_{2.33}$ but primarily as $\mathrm{U}_{4} \mathrm{O}_{9}$ or $\left.\mathrm{UO}_{2.25}\right)$; uranium octoxide $\left(\mathrm{U}_{3} \mathrm{O}_{8}\right)$; schoepite and metaschoepite, $\left(\mathrm{UO}_{2}\right)_{8} \mathrm{O}_{2}(\mathrm{OH})_{12} \cdot 12 \mathrm{H}_{2} \mathrm{O}$ and $\left(\mathrm{UO}_{2}\right)_{8} \mathrm{O}_{2}(\mathrm{OH})_{12} \cdot 10 \mathrm{H}_{2} \mathrm{O}$, respectively; becquerelite, $\mathrm{Ca}\left(\mathrm{UO}_{2}\right)_{6} \mathrm{O}_{4}(\mathrm{OH})_{6} \cdot 8\left(\mathrm{H}_{2} \mathrm{O}\right)$; and studtite, 
$\left[\left(\mathrm{UO}_{2}\right) \mathrm{O}_{2}\left(\mathrm{H}_{2} \mathrm{O}\right)_{2}\right]\left(\mathrm{H}_{2} \mathrm{O}\right)_{2}$ (Makenas et al. 1996-1999). The most prominent phases observed by XRD are $\mathrm{UO}_{2+\mathrm{x}}$ and schoepite.

The presence of uranium metal in the KE and KW Basin sludges has not been observed by XRD. However, it has been verified by the observation of hydrogen gas generated during sludge-water contact, and the concomitant release of interstitially trapped krypton and xenon gases, in isotopic ratios corresponding to those expected from uranium fission as the uranium metal corrodes (Delegard et al. 2000; Schmidt et al. 2003; Bryan et al. 2004).

Based on the relative abundance of $\mathrm{UO}_{2+\mathrm{x}}$ and schoepite and the expected ruggedness and size (including mass) of the uranium metal, the review of uranium sludge component properties was limited to these three materials. The other uranium-bearing compounds (e.g., $\mathrm{UH}_{3}$, becquerelite) are expected to be much less abundant and have properties encompassed by those of $\mathrm{UO}_{2+\mathrm{x}}$ and schoepite. Values for the mechanical properties of uranium metal (both in its non-irradiated form and after irradiation), $\mathrm{UO}_{2}$, and schoepite were collected from the technical literature and are presented in Table 2.2.

Table 2.2. Uranium Sludge Component Material Properties

\begin{tabular}{|c|c|c|c|c|c|c|c|c|c|}
\hline \multirow{3}{*}{ Material } & \multirow{3}{*}{$\begin{array}{c}\text { Integrated } \\
\text { Neutron } \\
\text { Flux, } \\
\text { n/cm² }\end{array}$} & \multirow{3}{*}{$\begin{array}{l}\text { Approx. } \\
\text { Exposure, } \\
\text { MWd/t }\end{array}$} & \multirow{3}{*}{$\begin{array}{c}\text { Particle } \\
\text { Density, } \\
\text { g/cm }\end{array}$} & \multicolumn{5}{|c|}{ Hardness } & \multirow{3}{*}{ References } \\
\hline & & & & \multirow[b]{2}{*}{ Moh } & \multirow[b]{2}{*}{ Vickers } & \multicolumn{3}{|c|}{ Rockwell Scale } & \\
\hline & & & & & & A & G & $\mathrm{C}$ & \\
\hline \multicolumn{10}{|l|}{ Uranium Metal } \\
\hline Alloy 601 ( $\beta$ phase $)$ & 0 & 0 & 19 & - & 250 & 62 & - & 23 & Weakley (1979) \\
\hline \multirow{3}{*}{ Uranium specimen } & 0 & 0 & 19 & - & 214 & 58 & - & $\sim 15$ & Bush (1960) \\
\hline & $3.3 \times 10^{19}$ & 126 & 19 & - & 275 & 64 & - & 27 & Bush (1960) \\
\hline & $3.3 \times 10^{20}$ & 1260 & 19 & - & 315 & 67 & - & 34 & Bush (1960) \\
\hline \multirow{2}{*}{$\begin{array}{l}\beta \text {-heat treated, center } \\
\text { softer than edge }\end{array}$} & 0 & 0 & 19 & - & - & $57-61$ & $71-78$ & $\sim 14-21$ & Bush (1957) \\
\hline & $7.2 \times 10^{19}$ & 274 & 19 & - & - & $63-65$ & \begin{tabular}{|l|}
$84-89$ \\
\end{tabular} & $25-29$ & Bush (1957) \\
\hline$\beta$-heat treated, center & $1.7 \times 10^{20}$ & 648 & 19 & - & - & $65-?$ & \begin{tabular}{|l|}
$89-94$ \\
\end{tabular} & $29-?$ & Bush (1957) \\
\hline$\beta$-heat treated, edge & $1.7 \times 10^{20}$ & 648 & 19 & - & - & $?-?$ & $98-103$ & $?-?$ & Bush (1957) \\
\hline \multicolumn{10}{|l|}{ Uranium Compounds } \\
\hline $\mathrm{UO}_{2}$ & - & - & 11 & $6-7$ & - & $79-83$ & - & $56-63$ & Belle (1961) \\
\hline $\begin{array}{l}\text { Schoepite, } \\
\left(\mathrm{UO}_{2}\right)_{8} \mathrm{O}_{2}(\mathrm{OH})_{12} \cdot 12 \mathrm{H}_{2} \mathrm{O}\end{array}$ & - & - & 4.8 & 2.5 & - & $\sim 24$ & - & $<2$ & $\begin{array}{l}\text { Roberts et al. } \\
(1990)\end{array}$ \\
\hline
\end{tabular}

It is seen that the uranium metal hardness increases steeply with irradiation. However, the exposures received by the uranium reported in the literature (up to $1260 \mathrm{MWd} / \mathrm{t}$ ) were significantly lower than the $\sim 3000 \mathrm{MWd} / \mathrm{t}$ exposures received by a large portion of the fuel contained in the K Basins (Packer 1999; Gibson 2000).

The hardness value presented in Table 2.2 for $\mathrm{UO}_{2}$ is as high, or higher, than hardness values presented in Table 2.1 for the non-uranium sludge phases, and the density is higher. It is also worthwhile to note that even though the individual $\mathrm{UO}_{2+\mathrm{x}}$ crystallite particle sizes resulting from the corrosion of uranium metal in water should be micron-scale, much larger (millimeter-scale) agglomerates or self-cemented accretions of uranium-rich materials or compounds have been observed in $\mathrm{K}$ Basin sludge (see, for example, Figures I.6.1-1 through -4 in Makenas et al. 1997 for sludge from the KE fuel storage canisters). Thus, $\mathrm{UO}_{2}$ likely is more mechanically aggressive in pump operations than any non-uranium sludge phase. In contrast, the hardness of schoepite is low in comparison with most other sludge phases. The planar structure of schoepite (similar to that of graphite, clays, and talc) may be responsible for this behavior. If so, other 
planar-structure hexavalent uranium [U(VI)] compounds in the sludge, including metaschoepite, becquerelite, and studtite, should likewise be soft.

Another parameter of importance with respect to creating a surrogate to test slurry-transport pumps and equipment for $\mathrm{K}$ Basin sludge is mechanical toughness. The toughness of non-irradiated uranium metal to fracture (e.g., impact strength) is high, as described by Hausner and Zambrow (1958):

On account of its ductility, uranium cannot be comminuted to a powder by mechanical means, such as milling, crushing, or grinding. Even at very low temperatures, uranium still is too ductile for this purpose.

The impact strength is measured by the resistance a notched specimen exhibits to breaking when struck with impacts of known force. The impact strength of non-irradiated uranium metal was found to be relatively high and comparable to that of hot-rolled Monel or Inconel (Paprocki and Saller 1952). The impact strength of heat-treated uranium (presumably $\beta$-phase), however, decreased by a factor of 3 after undergoing $10^{19}$ neutrons $/ \mathrm{cm}^{2}$ integrated flux, equivalent to about $40 \mathrm{MWd} / \mathrm{t}$ irradiation (Bush 1960).

The breaking strength of Hanford SPR 4-in.-long test uranium metal fuel slugs irradiated to $156 \mathrm{MWd} / \mathrm{t}$ and $856 \mathrm{MWd} / \mathrm{t}$ was measured using a "slug breaker" (Kratzer 1955), which consisted of two anvils with a $3 \frac{1}{2}$-in. space between them. The slug was placed such that it spanned the two anvils, and a downward force was applied midway between the supports. The force required to break the slug and the deflection at the point of breaking were measured. The slugs irradiated to $156 \mathrm{MWd} / \mathrm{t} l o s t \sim 20 \%$ of their original breaking strength (compared with the non-irradiated slugs), and the slugs irradiated to $834 \mathrm{MWd} / \mathrm{t}$ lost $\sim 60 \%$ of their original breaking strength.

Increased yield strength and sharply decreased elongation (loss of ductility) occur at low exposure, but show little further change to $1000 \mathrm{MWd} / \mathrm{t}$ (Table 2.3; Bush 1957). Over the same exposure span, ultimate (tensile) strength decreases about $20 \%$, with most of the decrease occurring at low exposure. According to Bush (1957), the decreased elongation is believed due to microcracking and fission products formed during irradiation.

Table 2.3. Uranium Metal Strength as a Function of Irradiation

\begin{tabular}{|c|c|c|c|c|}
\hline \multicolumn{2}{|c|}{ Exposure } & \multicolumn{2}{c|}{ Strength, psi } & $\begin{array}{c}\text { Elongation, } \\
\text { \% in 1 in. }\end{array}$ \\
\hline Atomic\% Burnup & $\sim$ MWd/t & Ultimate & $\mathbf{0 . 2 \% ~ Y i e l d ~}$ & 19.0 \\
\hline 0 & 0 & $9.71 \times 10^{4}$ & $3.77 \times 10^{4}$ & 0.75 \\
\hline 0.018 & 180 & $7.80 \times 10^{4}$ & $5.70 \times 10^{4}$ & 0.7 \\
\hline 0.031 & 310 & $8.30 \times 10^{4}$ & $7.30 \times 10^{4}$ & 0.5 \\
\hline 0.075 & 750 & $8.80 \times 10^{4}$ & $7.90 \times 10^{4}$ & 0.55 \\
\hline 0.10 & 1010 & $7.74 \times 10^{4}$ & $7.34 \times 10^{4}$ & \\
\hline
\end{tabular}

Despite the loss of ductility with exposure, qualitative evidence proves irradiated $\mathrm{N}$ Reactor fuel retrieved from the K Basins to be remarkably tough and resistant to fracture. This behavior was shown when attempts were made to crush pieces of irradiated fuel in a Plattner mortar and pestle [an open-ended cylindrical tool-steel chamber (mortar) with tool-steel piston (pestle)] (Schmidt et al. 2003):

Even though the metal fuel coupons subjected to crushing came from a highly damaged fuel element, and were fairly brittle (did not behave as a malleable metal), the crushing required very significant physical effort. Attempts were made to crush fuel from a 
broken, highly fractured, end piece of the element that weighed about $440 \mathrm{~g}$. The cladding was peeled from this end piece, and the exposed fuel was aggressively attacked using a pick and a hammer. However, after considerable effort, only about $20 \mathrm{~g}$ of fuel pieces were recovered for further crushing, and the end piece (now in three separate pieces) was returned to storage.

Similar qualitative observations of the toughness of irradiated uranium metal were made during examination and characterization testing of N Reactor fuel (Pitner 1997):

Despite the fragile physical appearance of some of the elements examined, they actually proved to retain substantial structural integrity. Considerable effort was required to physically break the elements or break fuel pieces free from the elements.

\subsection{Conclusions}

The technical literature for the density and hardness of the non-uranium and uranium sludge phases was surveyed. The density and hardness values show that the mechanical aggressiveness of the non-uranium sludge is bounded by quartz and basalt.

The density and hardness of the two primary uranium corrosion products, $\mathrm{UO}_{2}$ and schoepite, also were reported in the technical literature. The hardness of $\mathrm{UO}_{2}$ is equal to, or greater than, that of any nonuranium phase, and its density is higher. While $\mathrm{UO}_{2}$ particles are expected to be micron-scale, some accreted uranium-rich particles also have been observed in sludge. Therefore, the mechanical aggressiveness of $\mathrm{UO}_{2}$ is likely to be greater than that of any non-uranium sludge phase. Schoepite hardness and density are matched well by non-uranium sludge phases and contribute no added mechanical aggressiveness to the sludge.

The hardness of uranium metal reported in the literature was found to increase with radiation exposures. However, hardness values for metal exposed to the maximum levels experienced by N Reactor fuel are not published and must be measured. The technical literature shows uranium to be ductile and tough. The ductility of uranium decreases sharply at low exposures. The ultimate strength also decreases with irradiation, but still remains relatively high, as confirmed by qualitative observations during crushing and sampling of irradiated fuel. 


\subsection{N Reactor Fuel Hardness Measurements}

The hardness of N Reactor fuel irradiated to $\sim 2000-3000 \mathrm{MWd} / \mathrm{t}$ was measured to provide data at the irradiation levels consistent with the metal particles in the sludge. The measurements were made using existing irradiated uranium metal fuel coupons (from three fuel elements) available in the High Level Radiation Facility (HLRF) of the Radiochemical Processing Laboratory in the Hanford 300 Area. The three fuel elements had been removed from the K Basins and originally examined in the laboratory as part of past Spent Nuclear Fuel Project characterization activities for fuel storage options (e.g., Abrefah et al. 1999). The coupons used in the present study were retained for potential support of K Basin sludge processing efforts.

Although N Reactor fuel assemblies consist of concentric inner and outer tube-shaped elements, only coupons from the outer elements were available for testing. The bulk of the sludge is expected to have come from the corrosion of the outer elements, because most physical damage to the fuel assemblies, such as cracking of the cladding, occurred initially when these elements were discharged from the reactor. Once the cladding was breached, the metallic uranium fuel would be exposed to the basin waste and corrode. The outer elements would be more susceptible to fracture while protecting the inner elements from impact and damage.

The goals and performance of testing were defined in Test Instruction, "Hardness Measurement of Irradiated N Reactor Fuel Coupons," 46498-TI03, C. H. Delegard (Pacific Northwest National Laboratory), approved by Fluor Hanford engineering and project personnel, and cognizant scientists, engineers, and facility operation managers at PNNL.

\subsection{Sample Coupons for Hardness Testing}

The sample coupons to be tested were contained in two 1-gal sample cans (designated SNF Sample \#1 and SNF Sample \#2) in the A Cell of the HLRF. The samples were taken from three fuel elements: SFEC10,4366 and SFEC05,4378 (both from the KW Basin) and SFEC04,2540E (from the KE Basin) and had been stored under inert (argon) cover gas. All coupons, as well as associated crushed fuel (Schmidt et al. 2003), were packaged in glass containers within the two sample cans.

Table 3.1 shows the properties of the parent fuel elements. The prior sectioning operations conducted on these three fuel elements are illustrated, respectively, in Figures 3.1 through 3.3.

Table 3.1. Fuel Element Properties

\begin{tabular}{|l|c|c|c|c|c|}
\hline $\begin{array}{c}\text { Element, } \\
\text { Canister }\end{array}$ & Basin & Key & $\begin{array}{c}\text { Est. Burnup of } \\
\text { Fuel Key, } \\
\text { MWd/MTM }\end{array}$ & $\begin{array}{c}\text { Fuel } \\
\text { Type }\end{array}$ & ${ }^{240} \mathbf{P u , ~ \% ~}$ \\
\hline SFEC04,2540E & KE & $\begin{array}{c}11372 \\
\text { (sub key B/D) }\end{array}$ & $\begin{array}{c}2592 \\
{[1230 / 3560]}\end{array}$ & MKIV & $12 / 15$ \\
\hline SFEC05,4366 & KW & 13858 & {$[2200]$} & MKIV & 12 \\
\hline SFEC10,4378 & KW & 13858 & {$[2200]$} & MKIV & 12 \\
\hline
\end{tabular} \begin{tabular}{l} 
Key indicates the day the fuel was discharged from the reactor on a scale in which Day 1 is \\
September 26, 1944, the date of first criticality of B Reactor (Packer 1999). \\
Fuel burnup estimated from ${ }^{240}$ Pu concentration (Pitner 1995; Schwinkendorf 2002). \\
\hline
\end{tabular}




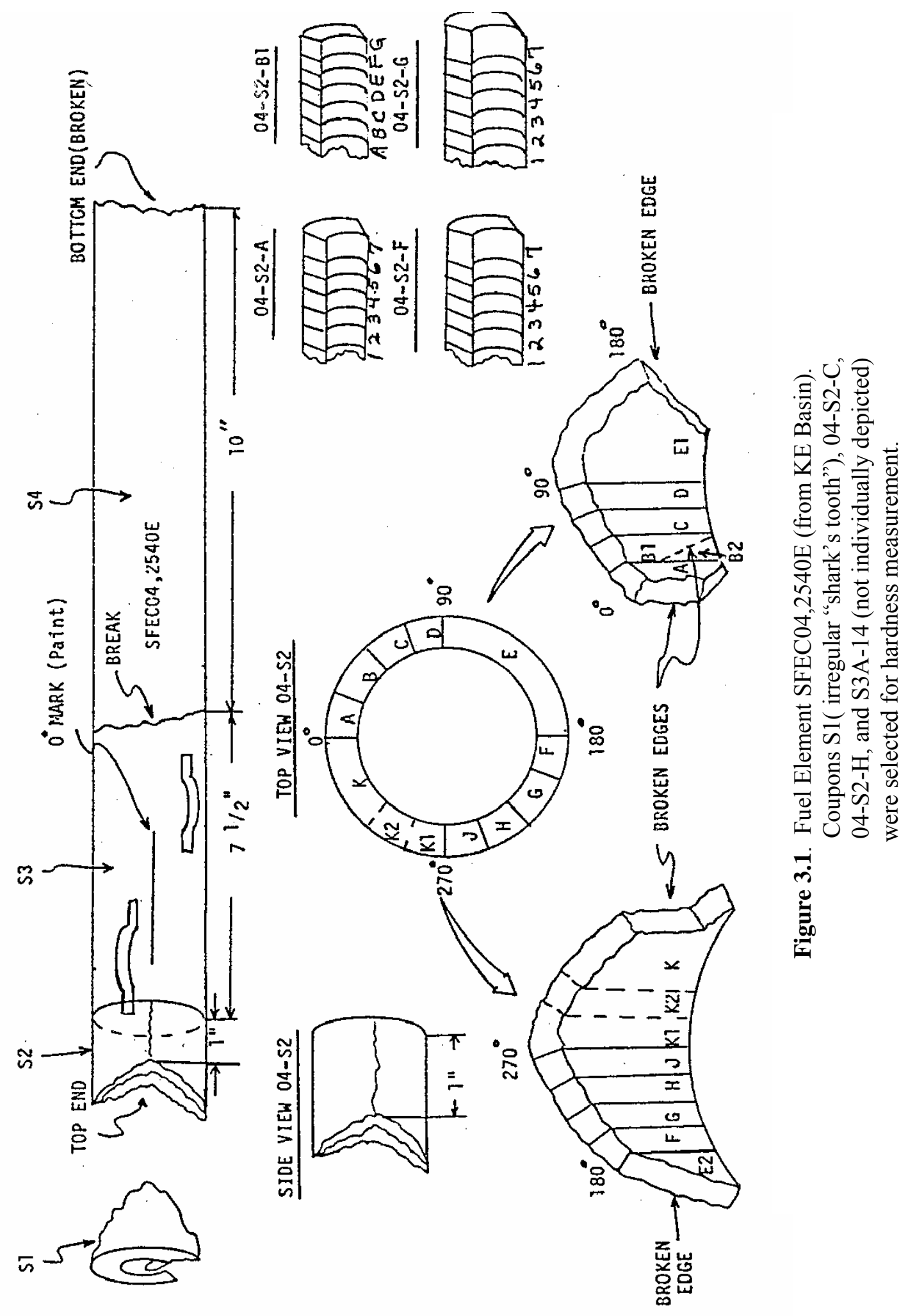




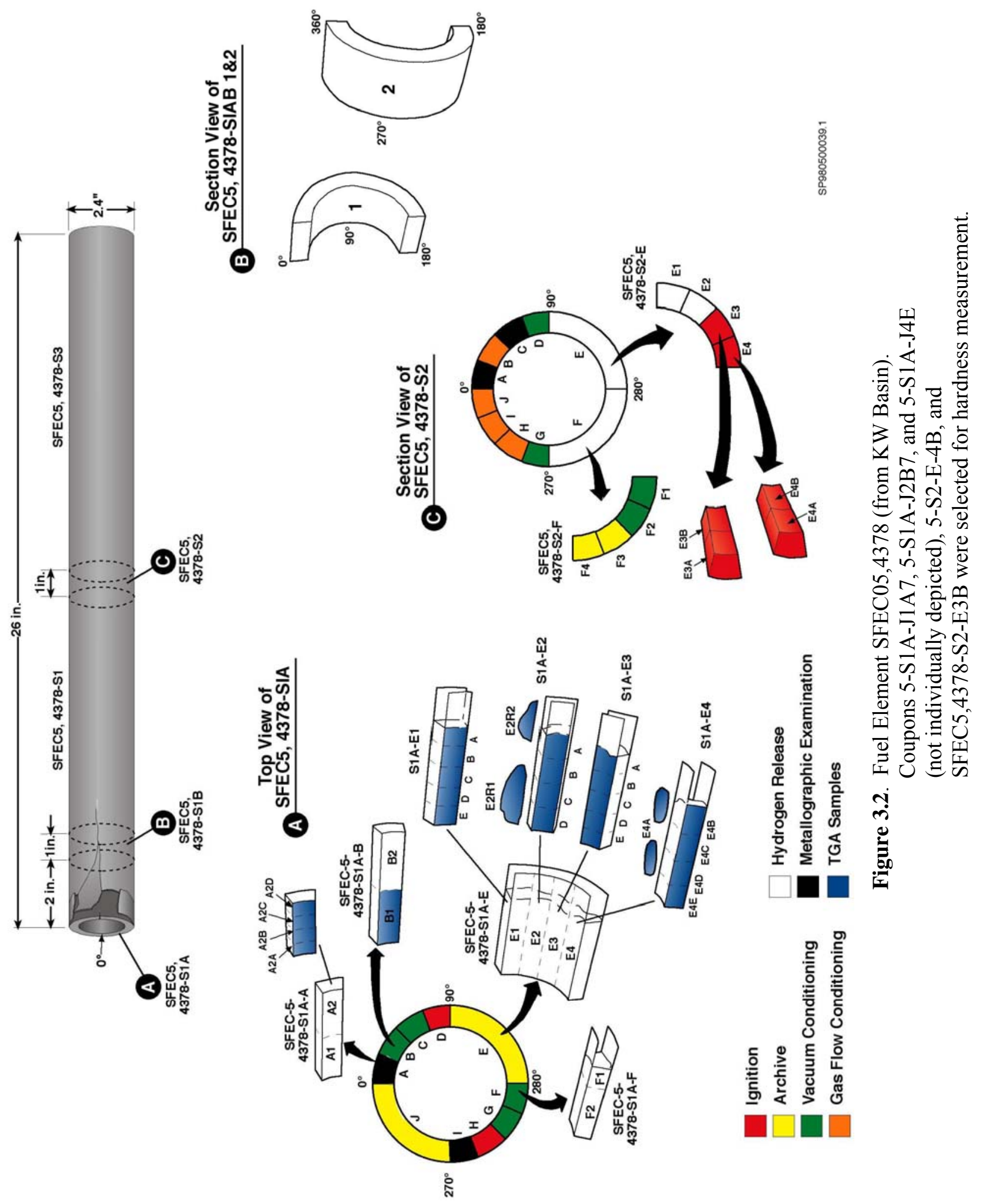




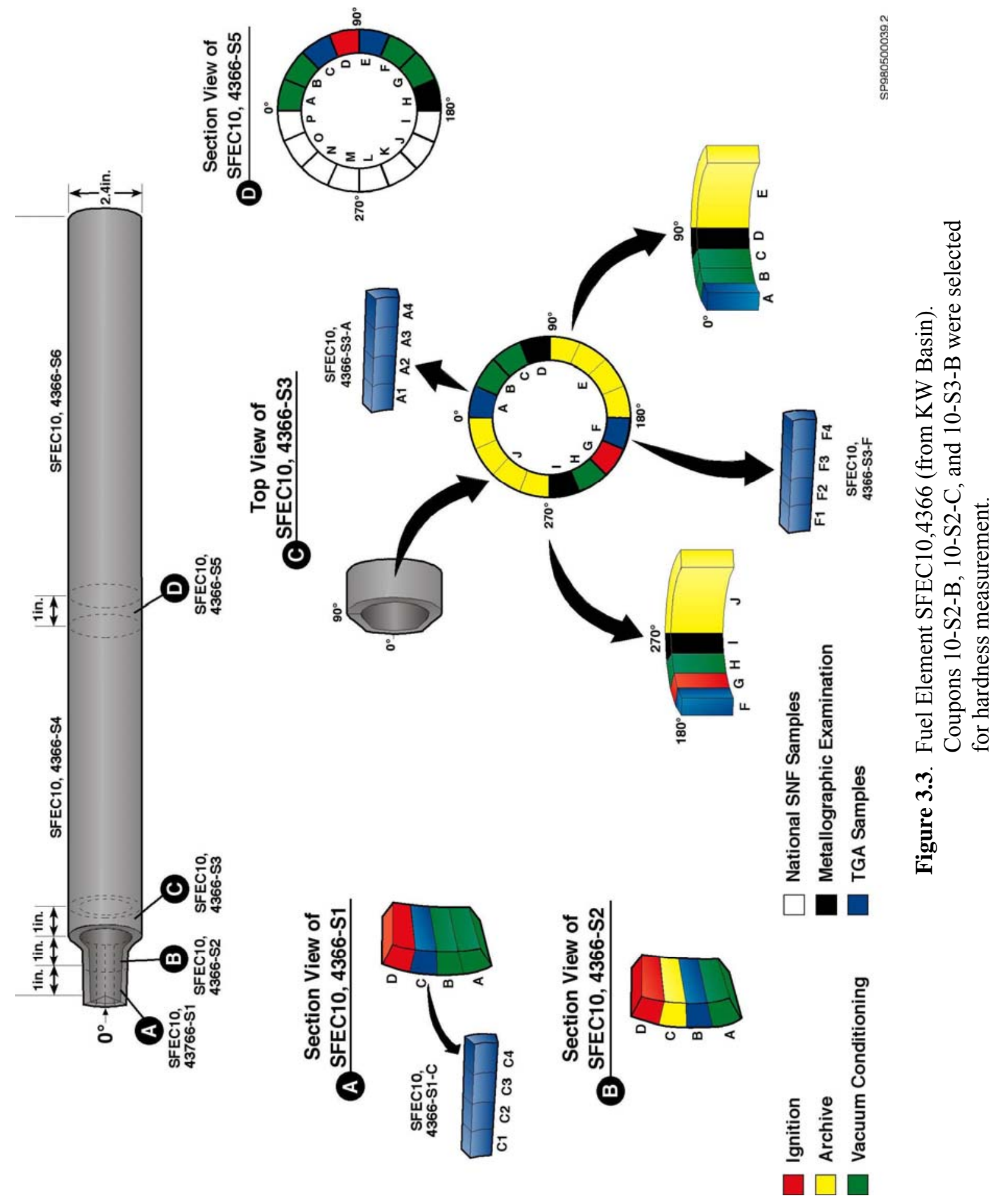


The fuel coupon inventories were taken by opening the sample cans, noting the sample numbers, and examining the coupons within their individual glass vials and jars. Samples of crushed fuel particles prepared as described by Schmidt et al. (2003) also were noted. Because the neutron flux and exposure varies both radially and axially in the N Reactor fuel (Schwinkendorf 2002), to the extent possible, samples also were selected from locations near the ends and the middle portions of the three fuel elements, and from faces directly under the cladding and within the "meat" of the fuel on cut faces. The Test Instructions called for at least three coupons, with a goal of 12; in fact, 12 coupons were measured.

In summary:

- Four of the 12 coupons were from SFEC04, five from SFEC5, and three from SFEC10 instead of the Test Instruction goals of four, three, and five, respectively.

- N Reactor fuel assemblies consist of concentric inner and outer tube-shaped elements. Although measurements of coupons from both inner and outer elements would have been desirable, no coupons from inner elements were available for testing. However, the outer elements, being more massive and susceptible to damage in handling than the inner elements, are likely the largest contributors to the uranium metal inventory in the sludge.

- Nine of the 12 coupons tested were from end or near-end locations, to represent the likelihood that such locations were more susceptible to fracture during fuel discharge at $\mathrm{N}$ Reactor.

- Three of the 12 coupons were from middle or near-middle locations.

Measurements of the hardness of cladding tightly bound to its underlying uranium metal were judged to be of less interest and were to be made opportunistically. In practice, and as would be expected based on the Zircaloy hardness data shown in Table 2.1, the fuel cladding was found to be too soft to be measured with the hardness tester, which is designed to measure in Rockwell $\mathrm{C}$ hardness units.

The origins of the fuel coupon segments tested, their parent fuel elements (all outer elements), and their locations within the respective element are summarized Table 3.2.

Table 3.2. Segments Selected for Hardness Testing

\begin{tabular}{|c|c|c|c|c|}
\hline \multirow{2}{*}{$\begin{array}{c}\text { Element/Segment } \\
\text { Number }\end{array}$} & \multirow{2}{*}{$\begin{array}{c}\text { Location: } \\
\text { End/Middle }\end{array}$} & \multirow{2}{*}{\begin{tabular}{c|} 
Distance from \\
End, in.
\end{tabular}} & \multicolumn{2}{|c|}{ Number of Coupons } \\
\hline & & & Goal & Actual \\
\hline \multicolumn{5}{|c|}{ SFEC04,2540E - taken from KE Basin } \\
\hline $\begin{array}{l}\text { S1 (large irregular piece; } \\
\text { "shark's tooth") }\end{array}$ & End & $0-1$ & 1 & 1 \\
\hline $\mathrm{S} 2$ & Near end & $1-2$ & 3 & 2 \\
\hline S3 & Near middle & $2-91 / 2$ & - & 1 \\
\hline \multicolumn{5}{|c|}{ SFEC5,4378 - taken from KW Basin } \\
\hline S1A & End & $0-2$ & 1 & $\begin{array}{l}3 \text { (incl. one from } \\
\text { two sides) }\end{array}$ \\
\hline $\mathrm{S} 2$ & Middle & $12-13$ & 2 & 2 \\
\hline \multicolumn{5}{|c|}{ SFEC10,4366 - taken from KW Basin } \\
\hline S1 & End & $0-1$ & \multirow[b]{2}{*}{3} & None available \\
\hline $\mathrm{S} 2$ & Near End & $1-2$ & & $\begin{array}{c}2 \text { (only coupons } \\
\text { available) }\end{array}$ \\
\hline S3 & Near End & $2-3$ & 1 & 1 \\
\hline S5 & Middle & $12-13$ & 1 & None available \\
\hline & & Total & 12 & 12 \\
\hline
\end{tabular}


The actual coupons used were selected based on which available samples also had reasonably parallel uranium metal faces that could be accommodated in the hardness tester. As Table 3.2 shows, the resulting total number of coupons and the distributions within source fuel elements and end-versusmiddle locations were matched as closely as possible to the original goals, taking into account that no inner element coupons were available.

\subsection{Hardness Testing Equipment and Procedure}

The Ames Model 1 Portable Hardness Tester (Figure 3.4) was selected based on its ASTM-compatible performance and amenability to use, after suitable adaptations, with master-slave manipulators at the hot cell. The Model 1 tester, with the flat anvil and diamond penetrometer, was modified by PNNL staff by adding a spoked fitting to the hand wheel. The grip (held by left hand in Figure 3.4) was placed in a weighted stand supplied by the vendor, and the stand was modified with a bale to allow transfer within the hot cell.

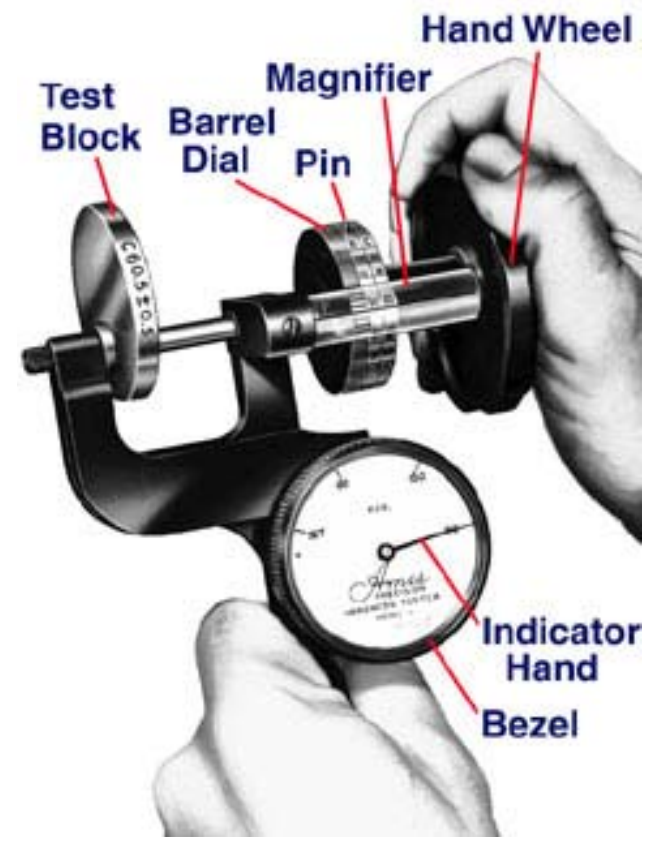

Figure 3.4. Ames Model 1 Portable Hardness Tester (illustration courtesy of Electro Arc Manufacturing Co., Ann Arbor, Michigan)

The hardness testing was conducted according to the guidance provided by ASTM (2002b), and followed the procedure provided in the "Operator's Manual, Ames Portable Hardness Testers for Rockwell Scales":

\section{Step 1.}

Check the position of the indicator hand. It should rest directly on the dot on the indicator dial. If it doesn't, adjust the dial by turning the bezel to locate the dot under the pointer. 


\section{Step 2: Apply Minor Load.}

Slowly turn the hand wheel to bring the indicator hand to the line marked "SET." This applies minor pressure load to the penetrometer. [Note, for the testing presented in this report, the hand wheel was modified with radial spokes for the hot cell use.]

\section{Step 3: Set the Barrel Dial.}

Rotate the barrel dial until its pin rests against the upper edge of the Lucite magnifier. The upper line of the barrel's hardness scales should be exactly aligned beneath the hairline on the magnifier.

\section{Step 4: Apply Major Load.}

Turn the hand wheel only until the dial pointer rests on the major load $[150 \mathrm{~kg}$ in this study]. Be careful to bring the indicator hand exactly to the desired graduation on the dial. ACCURACY: your tester is guaranteed to \pm 1 point Rockwell. When using this tester, you must use extreme care to position the pointer exactly on the minor and major load marks.

\section{Step 5: Take the Reading.}

Turn the hand wheel back to bring the indicator hand back to "SET" and take the reading on the barrel dial looking through the Lucite magnifier. Each graduation on the barrel dial indicates two points in the Rockwell scale.

\section{Standard Tester:}

With the diamond penetrator, read Column $\mathrm{C}$ on the barrel dial (black numbers).

The hardness of the Ames HRC certified test block, serial number 04k-16 (supplied with the instrument), was measured each day of testing to confirm the apparatus was operated properly and working correctly. According to the factory certificate, the test block has a Rockwell C hardness of 60.5 (measurable to \pm 1 unit). This measurement is traceable to National Institute of Standards and Technology Standard Reference Material 2812, "Rockwell C Scale Hardness - High Range," S/N 95N63057. Note that the test block was square, unlike the circular test block shown in Figure 3.4.

The coupon face being tested had to be near-perpendicular to the axis of the penetrometer. Furthermore, the coupon face dimensions had to be sufficiently large $(\sim 5 \mathrm{~mm} \times 5 \mathrm{~mm})$ to allow the penetrometer tip to be at least two and a half times the indentation diameter from any edge, and adjacent indentations to be at least one and a half times the indentation diameter from each other. Because visibility through the hot cell window and distance prevented distinct viewing of the small $(\sim 0.5$-mm-diameter) indentations, a video camera was used to examine the coupon during and after testing to verify that the test penetrations satisfied the spacing requirements. Similarly, the video camera was used for readings of the indicated hardness on the barrel dial.

\subsection{Hardness Measurement Results}

The Rockwell $\mathrm{C}$ hardness measurements of $\mathrm{N}$ Reactor fuel coupons were taken over a 3-day period. The test block hardness values obtained during this testing were $60,61,60,58,57$, and 60 (59.3 \pm 1.5$)$, compared with the average certified 60.5 Rockwell $\mathrm{C}$ hardness value. This performance was judged to be acceptable in accordance with equipment familiarization tests conducted before placing the device into the hot cell. 
The fuel coupon hardness results are summarized in Table 3.3 according to fuel element and location. The Rockwell C hardness values ranged from 15 to 49 and averaged $30 \pm 8$. These values are not appreciably different from the values reported for uranium irradiated to $1260 \mathrm{MWd} / \mathrm{t}$ (Table 2.2) and suggest that the hardness does not increase substantially with exposure going from 1260 to $\sim 3000 \mathrm{MWd} / \mathrm{t}$. A similar observation was made by Bleiberg et al. (1957) for uranium-molybdenum alloys irradiated to almost $9000 \mathrm{MWd} / \mathrm{t}$. These observations also are in line with the elongation (ductility) trends for uranium shown in Table 2.3.

Table 3.3. Hardness Measurement Results for N Reactor Fuel Coupons

\begin{tabular}{|c|c|c|c|c|}
\hline Coupon Number ${ }^{(a)}$ & Mass, g & Approx. Size, mm & Location & \begin{tabular}{|c|} 
Hardness, \\
Rockwell C
\end{tabular} \\
\hline \multicolumn{5}{|l|}{ SFEC04,2540E } \\
\hline 04-S1-2450E & 124.23 & \begin{tabular}{|l|} 
Irreg. "shark's tooth" \\
$30 \mathrm{~mm}$ high
\end{tabular} & $\begin{array}{l}\text { At surface under cladding (i.e., } \\
\text { cladding had been removed or was } \\
\text { gone); outer element at end }\end{array}$ & $23,26,24$ \\
\hline 04-S2-C & 26.94 & $25 \times 6 \times 6$ & $\begin{array}{l}\text { At cut surface } \sim \text { midway between } \\
\text { cladding; outer element near end }\end{array}$ & $\begin{array}{l}32,44,48 \\
\text { (near crack) }\end{array}$ \\
\hline 04-S2-H & 22.47 & $22 \times 6 \times 6$ & $\begin{array}{l}\text { At cut surface (i.e., not under } \\
\text { cladding); outer element near end }\end{array}$ & $\begin{array}{l}26,27,20 \\
36 \text { (near } \\
\text { cladding) } \\
\end{array}$ \\
\hline S3A-14 & 28.00 & $22 \times 6 \times 6$ & $\begin{array}{l}\text { At cut surface; outer element } \\
2-91 / 2 \text { in. from end }\end{array}$ & $\begin{array}{l}29 \text { (near outer } \\
\text { cladding), } 17, \\
19\end{array}$ \\
\hline \multicolumn{5}{|l|}{ SFEC5,4378 } \\
\hline 5-S1A-J1A7 & 14.27 & $25 \times 6 \times 6$ & $\begin{array}{l}\text { At cut surface } \sim 1 / 8 \text { in. away under } \\
\text { cladding; outer element at end }\end{array}$ & $25,30,34$ \\
\hline \multirow[b]{2}{*}{ 5-S1A-J2B7 } & \multirow[b]{2}{*}{8.58} & \multirow[b]{2}{*}{$22 \times 12 \times 3$} & At cut surface; outer element at end & $24,35,25,29$ \\
\hline & & & $\begin{array}{l}\text { At surface under cladding (opposite } \\
\text { from cut surface) after cladding had } \\
\text { broken off in handling; outer } \\
\text { element at end }\end{array}$ & $\begin{array}{l}43,36,35,21 \\
49,43\end{array}$ \\
\hline 5-S1A-J4E & 18.57 & $16 \times 6 \times 6$ & $\begin{array}{l}\text { At cut surface midway between } \\
\text { cladding; outer element at end }\end{array}$ & 33,39 \\
\hline 5-S2-E-4B & 9.95 & $12 \times 6 \times 6$ & $\begin{array}{l}\text { At cut surface } \sim \text { midway between } \\
\text { cladding; outer element at middle }\end{array}$ & $32,34,29$ \\
\hline SFEC5,4378-S2-E3B & 13.95 & $12 \times 6 \times 6$ & $\begin{array}{l}\text { At cut surface } \sim \text { midway between } \\
\text { cladding; outer element at middle }\end{array}$ & $31,37,44$ \\
\hline \multicolumn{5}{|l|}{ SFEC10,4366 } \\
\hline 10-S2-B & 20.48 & $16 \times 6 \times 6$ & $\begin{array}{l}\text { At cut surface } \sim \text { midway between } \\
\text { cladding; outer element at end }\end{array}$ & $15,26,27$ \\
\hline $10-\mathrm{S} 2-\mathrm{C}$ & 18.13 & $12 \times 6 \times 6$ & $\begin{array}{l}\text { At cut surface all near outer } \\
\text { cladding; outer element at end }\end{array}$ & $19,26,25$ \\
\hline 10-S3-B & 64.92 & $35 \times 6 \times 6$ & $\begin{array}{l}\text { At cut surface between cladding; } \\
\text { outer element near end }\end{array}$ & $30,29,25,22$ \\
\hline
\end{tabular}

Generally, for a given coupon, greater hardness was found near or under the cladding than within the meat of the fuel away from cladding. This is most evident for coupon 5-S1A-J2B7, which had Rockwell $\mathrm{C}$ hardness values directly under the cladding averaging $38 \pm 6$ compared with hardness values found on the parallel cut face $\sim 3 \mathrm{~mm}$ away in the meat averaging $28 \pm 5$. Part of the reason for greater hardness 
may be that the fuel near the cladding experiences greater thermal neutron exposure (due to water moderation) than the fuel away from the cladding (Schwinkendorf 2002). Another potential reason is that the close swaging of the Zircaloy cladding with the uranium metal fuel may have created a zirconiumuranium alloy. Uranium-2 wt\% zirconium alloy itself has a Rockwell A hardness of $\sim 70$, equivalent to Rockwell C of $\sim 40$, and the hardness of the uranium- $2 \mathrm{wt} \%$ zirconium fuel remains unchanged by irradiation (Murphy et al. 1962). This value is near the hardness observed here directly under the cladding. The coupon before, during, and after hardness measurement is displayed in Figure 3.5.

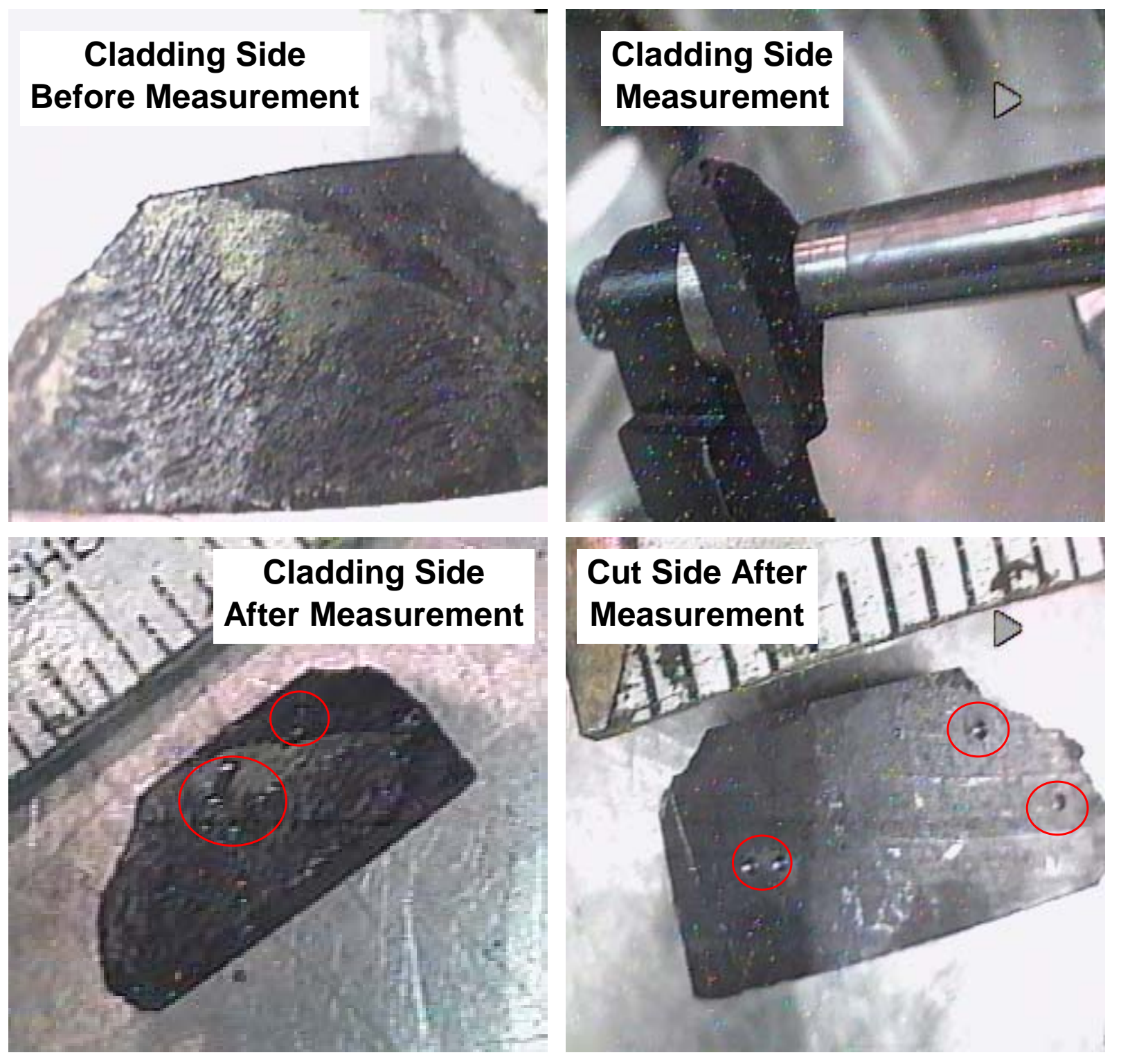

Figure 3.5. Coupon 5-S1A-J2B7 Before, During, and After Hardness Measurements.

Cladding Side: Note six hardness measurement indentations within larger circle and two indentations on cracked sloping face (not used) in smaller circle. Cut Side: Note four hardness measurement indentations within circles. 
No particular trend in hardness was found from the end to the middle of a particular element. For example, the results for element SFEC04,2450E in coupons 04-S2-C, 04-S2-H, and S3A-14 progressed to lower values from near the end to near the middle, while the trend was generally in the opposite direction for element SFEC5,4378. The six hardness measurements taken from the section one to two inches from the end of element SFEC10,4366 (Rockwell C of $23 \pm 5$ ) were not significantly different from those observed in the third inch from the end section of the same element (Rockwell C of $26 \pm 4$ ).

The hardness of a coupon of non-irradiated SPR uranium metal fuel was measured using another Ames Model 1 hardness tester. The average Rockwell $\mathrm{C}$ hardness was $15 \pm 3$, not significantly different from that reported in past testing (Bush 1957, 1960; as summarized in Table 2.2 of this report). 


\subsection{Uranium Material Surrogates}

Surrogates are required for irradiated uranium metal and $\mathrm{UO}_{2+\mathrm{x}}$, while the hardness and small particle size of schoepite suggest its properties may be covered conservatively by other non-uranium components (e.g., quartz). The mechanical properties important for slurry pumping of uranium metal also include impact strength ("toughness to fracture") and ductility. Thus, parameters evaluated for uranium metal and its surrogates also include ultimate tensile strength and elongation upon fracture. Candidate surrogate materials and their properties compared with the same properties of the actual uranium metal and $\mathrm{UO}_{2+\mathrm{x}}$ sludge phases are presented in Table 4.1. The suitability of the candidate surrogates is discussed below.

As shown in Table 4.1, irradiated uranium metal properties are most closely fit by the tungsten alloys, which have densities very near that of uranium, as well as similar hardness. The ultimate yield strengths of the tungsten alloys are generally higher, as is the elongation at failure, but are still closer to those of irradiated uranium than these same parameters for Monel and 304 stainless steel. The fracture resistance of pure tungsten and the alloys richer in tungsten content is poor; however, toughness improves with decreasing tungsten content. Therefore, of the materials identified, the tungsten-based material, Densalloy SD170 or equivalent, is recommended as the irradiated uranium metal surrogate having the best combination of density, hardness, and strength.

The cobalt-cemented tungsten carbide (W/Co), despite its high density, is a less suitable surrogate owing to its extreme hardness, thus making it a highly conservative surrogate for the uranium metal fuel for slurry equipment testing. Measurements of the hardness of W/Co obtained from Kennametal and used in initial slurry pump engineering testing were performed using the Ames Model 1 hardness tester. The measurements, averaging 69 and 74 for two pieces, confirm the reported Rockwell C hardness of $>68$. Hardness tests of the tungsten granules also used in prior slurry simulants were attempted but could not be completed. The granules apparently were in the form of loosely sintered powder aggregates that shattered when significant force was applied through the penetrometer. Thus, tungsten-based surrogates should also be selected to match the strength qualities of irradiated uranium metal.

Garnet, a class of mineral with general formula $(\mathrm{Ca}, \mathrm{Fe}, \mathrm{Mg}, \mathrm{Mn})_{3}(\mathrm{Al}, \mathrm{Fe}, \mathrm{Mn}, \mathrm{Cr}, \mathrm{Ti}, \mathrm{V})_{2}\left(\mathrm{SiO}_{4}\right)_{3}$, was used in Integrated Water Treatment System testing for the KW Basin (Mauws and Bergsman 1999; Bridges 2000). However, garnet is too hard and its density too low to be readily comparable with the same properties of irradiated uranium metal in high flow velocity situations. The qualities of garnet are near those of quartz sand, a non-radioactive sludge component. Use of garnet as a sludge component surrogate does not contribute, except perhaps size, to qualities represented by quartz sand.

Candidate surrogate materials for $\mathrm{UO}_{2}$ include $\mathrm{A} 434 \mathrm{~L}$ stainless steel (used in some sludge simulants), ceria $\left(\mathrm{CeO}_{2}\right)$, and hardened steel grit. None of the surrogate materials match the density of $\mathrm{UO}_{2}$, but the ceria and steel grit have similar hardness. The $\mathrm{UO}_{2+\mathrm{x}}$ present in the $\mathrm{K}$ Basin sludge has micron-size crystallites but, as described earlier, can be present in millimeter-sized agglomerates. These agglomerates do not readily crumble even with pressing under the fingers of a hot cell manipulator. The $\mathrm{CeO}_{2}$ surrogate proposed in Table $4.1(80 \mathrm{wt} \%<22 \mu \mathrm{m}, 50 \%<15 \mu \mathrm{m}, 20 \%<4 \mu \mathrm{m})$ can cover the lower range of the $\mathrm{UO}_{2+x}$ particle size distribution, while the proposed steel grit surrogate can represent the $\mathrm{UO}_{2+\mathrm{x}}$ agglomerates. It is important to note that the smaller, micron-sized particles can abrade pump seals and other closely fitting rotating wear surfaces. Thus, the $\mathrm{CeO}_{2}$ surrogate (or similarly hard and small particle size material) is an important constituent in a pump system durability test loop. 
Table 4.1. Uranium Sludge Component and Surrogate Material Properties

\begin{tabular}{|c|c|c|c|c|c|c|c|c|c|}
\hline \multirow{3}{*}{ Material } & \multirow{3}{*}{$\begin{array}{l}\text { Approx. } \\
\text { Exposure, } \\
\text { MWd/t }\end{array}$} & \multirow{3}{*}{$\begin{array}{c}\text { Particle } \\
\text { Density, } \\
\text { g/cm }\end{array}$} & \multirow{3}{*}{$\begin{array}{c}\text { Ult. Tens. } \\
\text { Strength., } \\
\text { psi } \\
\text { Elong., \% }\end{array}$} & \multicolumn{5}{|c|}{ Hardness } & \multirow{3}{*}{ References } \\
\hline & & & & \multirow[b]{2}{*}{ Moh } & \multirow[b]{2}{*}{ Vickers } & \multicolumn{3}{|c|}{ Rockwell, Scale } & \\
\hline & & & & & & A & $\mathbf{G}$ & $\mathbf{C}$ & \\
\hline \multicolumn{10}{|l|}{ Uranium Metal } \\
\hline $\begin{array}{l}\text { Alloy } 601 \text { ( } \beta \text { phase); } \\
\text { N Reactor fuel }\end{array}$ & 0 & 19 & $\begin{array}{c}1.13 \times 10^{5}, \\
8.6\end{array}$ & - & 250 & 62 & - & 23 & Weakley (1979) \\
\hline \multirow{3}{*}{ Uranium specimen } & 0 & - & - & - & 214 & 58 & - & $\sim 15$ & Bush (1960) \\
\hline & 126 & - & - & - & 275 & 64 & - & 27 & Bush (1960) \\
\hline & 1260 & - & - & - & 315 & 67 & - & 34 & Bush (1960) \\
\hline \multirow{2}{*}{$\begin{array}{l}\beta \text {-heat treated, center } \\
\text { softer than edge }\end{array}$} & 0 & - & - & - & - & $57-61$ & $71-78$ & ～14-21 & Bush (1957) \\
\hline & 274 & - & - & - & - & $63-65$ & $84-89$ & $25-29$ & Bush (1957) \\
\hline$\beta$-heat treated, center & 648 & - & - & - & - & $65-?$ & $89-94$ & $29-?$ & Bush (1957) \\
\hline$\beta$-heat treated, edge & 648 & - & - & - & - & $?-?$ & $98-103$ & $?-?$ & Bush (1957) \\
\hline Hanford U fuel & 0 & - & $9.7 \times 10^{4}, 19$ & - & - & - & - & - & Bush (1957) \\
\hline Hanford U fuel & 1010 & - & $7.7 \times 10^{4}, 0.5$ & - & - & - & - & - & Bush (1957) \\
\hline N Reactor Fuel & $\begin{array}{l}\sim 2000- \\
3000\end{array}$ & - & - & - & - & - & - & $30 \pm 8$ & Present tests \\
\hline \multicolumn{10}{|c|}{\begin{tabular}{|l|} 
Candidate Uranium Metal Surrogates \\
\end{tabular}} \\
\hline $\begin{array}{l}\text { Tool steel (e.g., } \\
\text { Plattner mortar \& } \\
\text { pestle) } \\
\end{array}$ & - & 8.2 & - & - & - & $81-83$ & - & $60-63$ & Ross (1992) \\
\hline $\begin{array}{l}\text { W/Co (cobalt- } \\
\text { cemented tungsten } \\
\text { carbide) }\end{array}$ & - & $14-15$ & - & - & - & $88-92$ & - & $>68$ & $\begin{array}{l}\text { Kennametal; } \\
\text { 800-458-3608 }\end{array}$ \\
\hline Tungsten & - & 19.3 & $2.2 \times 10^{3}$ & - & - & 62 & - & 23 & Ross (1992) \\
\hline Tungsten wire & - & 19.3 & $6.53 \times 10^{4}$ & - & - & 74 & - & 47 & Ross (1992) \\
\hline $\begin{array}{l}\text { Densalloy SD185; } 97 \\
\text { wt } \% \text { W }\end{array}$ & - & 18.5 & $1.1 \times 10^{5}, 2$ & - & - & - & - & 29 & $\begin{array}{l}\text { Tungsten } \\
\text { Products. }\end{array}$ \\
\hline $\begin{array}{l}\text { Densalloy SD170; } 90 \\
\text { wt } \% \text { W }\end{array}$ & - & 17.1 & $1.2 \times 10^{5}, 10$ & - & - & - & - & 28 & $\begin{array}{l}\text { Products; } \\
888-778-0979\end{array}$ \\
\hline 304 stainless steel & - & 7.85 & $8.4 \times 10^{4}, 50$ & - & - & 55 & - & $\sim 13$ & Ross (1992) \\
\hline Monel 400 & - & 8.8 & $1.1 \times 10^{5}, 7$ & - & - & 57 & - & $\sim 14$ & Ross (1992) \\
\hline Garnet & - & $3.2-4.3$ & - & $\begin{array}{l}6.5- \\
7.5 \\
\end{array}$ & - & $81-85$ & - & $60-65$ & $\begin{array}{l}\text { Roberts et al. } \\
(1990)\end{array}$ \\
\hline \multicolumn{10}{|l|}{ Uranium Dioxide } \\
\hline $\mathrm{UO}_{2}$ & - & 11 & - & $6-7$ & - & $79-83$ & - & $56-63$ & Belle (1961) \\
\hline \multicolumn{10}{|c|}{ Candidate $\mathbf{U O}_{2+\mathrm{x}}$ Surrogates } \\
\hline A434L stainless steel & - & 7.8 & - & - & - & $51-53$ & - & $\sim 2-6$ & Ross (1992) \\
\hline $\begin{array}{l}\mathrm{CeO}_{2} \text { (product } 5310, \\
50 \%<15.1 \mu \mathrm{m})\end{array}$ & - & 7.13 & - & $5-6$ & - & $71-79$ & - & $41-56$ & $\begin{array}{c}\text { Kilbourn } \\
\text { (1992); } \\
\text { Molycorp, } \\
\text { 760-856-2344 }\end{array}$ \\
\hline $\begin{array}{l}\text { Steel grit }(\mathrm{HG} \\
\text { hardness; G40 - } \\
100 \%<1000 \mu \mathrm{m}, \\
30 \%<425 \mu \mathrm{m}, 20 \% \\
<300 \mu \mathrm{m})\end{array}$ & - & 8.2 & - & - & - & $\begin{array}{c}\sim 70- \\
80\end{array}$ & - & $40-60+$ & $\begin{array}{c}\text { Abrasives } \\
\text { Northwest, } \\
\text { 206-575-0735 }\end{array}$ \\
\hline
\end{tabular}




\subsection{References}

Abrefah J., F. F. Huang, W. M. Gerry, W. J. Gray, S. C. Marschman, and T. A. Thornton. 1999. Analysis of Ignition Testing on K-West Basin Fuel. PNNL-11816, Pacific Northwest National Laboratory, Richland, WA.

ASTM. 2002a. "Standard Hardness Conversion Tables for Metals Relationship Among Brinell Hardness, Vickers Hardness, Rockwell Hardness, Superficial Hardness, Knoop Hardness, and Scleroscope Hardness." Standard E 140-02, American Society for Testing and Materials, West Conshohocken, PA.

ASTM. 2002b. "Standard Test Method for Indentation Hardness of Metallic Materials by Portable Hardness Testers." Standard E 110-82 (re-approved 2002), American Society for Testing and Materials, West Conshohocken, PA.

Baker, R. B. 2001. Estimated Volume of Sludge in the Hanford K East and K West Basins. HNF-8118, Fluor Hanford Co., Richland, WA.

Belle, J. 1961. Uranium Dioxide: Properties and Nuclear Applications, pp. 209 \& 671. US Atomic Energy Commission, Washington, DC.

Bleiberg, M. L., J. D. Eichenberg, R. H. Fillnow, and L. J. Jones. 1957. Development and Properties of Uranium-Base Alloys Corrosion Resistant in High Temperature Water. Part IV. Radiation Stability of Uranium-Base Alloys. WAPD-127 (Pt. IV), Westinghouse Electric Corporation, Bettis Plant, Pittsburgh, PA.

Bridges, A. E. 2000. Evaluation of the Submersible Pump Design for the K Basin Integrated Water Treatment System - Project A.9. SNF-6121, Fluor Hanford Co., Richland, WA.

Bryan, S. A., C. H. Delegard, A. J. Schmidt, R. L. Sell, K. L. Silvers, S. R. Gano, and B. M. Thornton. 2004. Gas Generation from K East Basin Sludges - Series II Testing. PNNL-13446, Rev. 1, Pacific Northwest National Laboratory, Richland, WA.

Bush, S. H. 1957. Irradiation Effects in Uranium. HW-51444, Hanford Atomic Products Operation, General Electric Co., Richland, WA.

Bush, S. H. 1960. Volume 1, "Materials," in Reactor Handbook, $2^{\text {nd }}$ edition, Table 7.22, p. 134, C. R. Tipton, Jr., editor. Interscience Publications, NY.

Delegard, C. H., S. A. Bryan, A. J. Schmidt, P. R. Bredt, C. M. King, R. L. Sell, L. L. Burger, and K. L. Silvers. 2000. Gas Generation from K East Basin Sludges - Series I Testing. PNNL-13320, Pacific Northwest National Laboratory, Richland, WA.

Gibson, K. D. 2000. K Basin Safety Analysis Report. WHC-SD-WM-SAR-062, Rev. 4, Fluor Hanford Inc., Richland, WA. 
Hausner, H. H., and J. L. Zambrow. 1958. "Powder Metallurgy of Uranium," Chapter 5 in Powder Metallurgy in Nuclear Engineering, H. H. Hausner, editor. American Society for Metals, Cleveland, OH.

Kilbourn, B. T. 1992. Cerium - A Guide to Its Role in Chemical Technology, Molycorp, Inc., White Plains, NY.

Kratzer, W. K. 1955. Examination of Irradiated Uranium-Chromium Alloy Slugs. HW-35189, Hanford Atomic Products Operation, General Electric Co., Richland, WA.

Ladoo, R. B. 1960. “Abrasives.” Chapter 1 in Industrial Minerals and Rocks, J. L. Gillson, editor. American Institute of Mining, Metallurgical, and Petroleum Engineers, NY.

Majzlan, J., A. Navrotsky, and U. Schwertmann. 2004. "Thermodynamics of Iron Oxides: Part III. Enthalpies of Formation and Stability of Ferrihydrite $\left(\sim \mathrm{Fe}(\mathrm{OH})_{3}\right)$, Schwertmannite $\left(\sim \mathrm{FeO}(\mathrm{OH})_{3 / 4}(\mathrm{SO} 4)_{1 / 8}\right)$, and $\varepsilon-\mathrm{Fe}_{2} \mathrm{O}_{3} . "$ Geochimica et Cosmochimica Acta 68(5):1049-1059.

Makenas, B. J., T. L. Welsh, R. B. Baker, D. R. Hansen, and G. R. Golcar. 1996. Analysis of Sludge from Hanford K East Basin Floor and Weasel Pit. WHC-SP-1182, Westinghouse Hanford Company, Richland, WA.

Makenas, B. J., T. L. Welsh, R. B. Baker, E. W. Hoppe, A. J. Schmidt, J. Abrefah, J. M. Tingey, P. R. Bredt, and G. R. Golcar. 1997. Analysis of Sludge from Hanford K East Basin Canisters. HNF-SP-1201, Duke Engineering and Services Hanford, Inc., Richland, WA.

Makenas, B. J., T. L. Welsh, R. B. Baker, G. R. Golcar, P. R. Bredt, A. J. Schmidt, and J. M. Tingey. 1998. Analysis of Sludge from Hanford K West Basin Canisters. HNF-1728, Rev. 0, Fluor Daniel Hanford, Richland, WA.

Makenas, B. J., T. L. Welsh, P. R. Bredt, G. R. Golcar, A. J. Schmidt, K. L. Silvers, J. M. Tingey, A. H. Zacher, and R. B. Baker. 1999. Analysis of Internal Sludge and Cladding Coatings from N-Reactor Fuel Stored in Hanford K Basins. HNF-3589, Rev. 0, Fluor Daniel Hanford, Richland, WA.

Mauws, L. C., and K. H. Bergsman. 1999. Integrated Water Treatment System - K West Knockout Pot Screen Erosion and Impact Analysis. SNF-4729, Rev. 0, Fluor Daniel Hanford, Richland, WA.

Murphy, W. F., A. C. Klank, and S. H. Paine. 1962. Examination of Uranium-2 Wt\% Zirconium Experimental Fuel Slugs Irradiated in EBR-I. Final Report-Program 6.1.11. ANL-6114, Argonne National Laboratory, Idaho Falls, ID.

Paprocki, S. J., and H. A. Saller. 1952. Notched-Bar Impact Testing of Uranium. BMI-753, Battelle Memorial Institute, Columbus, $\mathrm{OH}$.

Packer, M. J. 1999. 105-K Basin Material Design Basis Feed Description for Spent Nuclear Fuel Project Facilities. HNSD-SNF-TI-009, Vol. 1, Rev. 3, Numatec Hanford Co., Richland, WA.

Pearce, K. L. 2001. 105-K Basin Material Design Basis Feed Description for Spent Nuclear Fuel Project Facilities. HNF-SD-SNF-TI-009, Vol. 2, Rev. 4. Fluor Hanford Co., Richland, WA. 
Pitner, A. L. 1995. K East Underwater Visual Survey. WHC-SD-SNF-TI-012, Rev. 0., Westinghouse Hanford Co., Richland, WA.

Pitner, A. L. 1997. K Basin Fuel Subsurface Examination and Surface Coating Sampling. HNF-SD-SNF-TI-060, Rev. 0, Duke Engineering and Services Hanford, Inc., Richland, WA.

Roberts, W. L., T. J. Campbell, G. R. Rapp, and W. E. Wilson. 1990. Encyclopedia of Minerals, $2^{\text {nd }}$ edition. Van Nostrand Reinhold, NY.

Ross, R. B. 1992. Metallic Materials Specification Handbook, $4^{\text {th }}$ edition. Chapman \& Hall, London.

Schmidt, A. J., C. H. Delegard, S. A. Bryan, M. R. Elmore, R. L. Sell, K. L. Silvers, S. R. Gano, and B. M. Thornton. 2003. Gas Generation from K East Basin Sludges and Irradiated Metallic Uranium Fuel Particles - Series III Testing. PNNL-14346, Pacific Northwest National Laboratory, Richland, WA.

Schmidt, A. J. 2004. Spent Nuclear Fuel Project Databook, Vol. 2, Sludge. HNF-SD-TI-015, Rev. 12, Fluor Hanford Co., Richland, WA.

Schwinkendorf, K. N. 2002. K East Basin Sludge Characterization Using Exposure Source Terms for N Reactor Fuel. HNF-8760, Rev. 0, Attachment 16, Fluor Hanford Co., Richland, WA.

Weakley, E. A. 1979. Fuels Engineering Technical Handbook. UNI-M-61, UNC Nuclear Industries, Richland, WA. 